\title{
Aspartate carbamoyltransferase from a psychrophilic deep-sea bacterium, Vibrio strain 2693: properties of the enzyme, genetic organization and synthesis in Escherichia coli
}

\author{
Ying $\mathrm{Xu}_{1}{ }^{1,2}$ Yuanfu Zhang, ${ }^{4}$ Ziyuan Liang, ${ }^{1}$ Mark Van de Casteele, ${ }^{1,2}$ \\ Christianne Legrain ${ }^{3}$ and Nicolas Glansdorff ${ }^{1,2,3}$
}

\begin{abstract}
Author for correspondence: Nicolas Glansdorff. Tel: +32252672 75. Fax: +3225267273 .
\end{abstract} e-mail: ceriair@ulb.ac.be
1,2,3 Microbiologie, Vrije Universiteit Brussel1, Flanders Interuniversity Institute for Biotechnology 2 and Research Institute CERIA-COOVI 3 , Emile Grysonlaan 1, B-1070 Brussels, Belgium
4 Epidemiology Institute, Beijing, The Peoples Republic of China

\begin{abstract}
The aspartate carbamoyltransferase (ATCase) genes of psychrophilic Vibrio strain 2693 were cloned by complementation in Escherichia coli and the enzyme was partly characterized. The genes constitute a pyrBI operon homologous to the cognate structure in E. coli where pyrB and pyrI respectively encode the catalytic and the regulatory chains of ATCase. The strong sequence similarities noted between Vibrio and E. coli ATCases include extensive conservation of residues involved in interactions between subunits, suggesting that the two enzymes have very similar tertiary and quaternary structures. Vibrio ATCase is, however, not activated by ATP and not synergistically inhibited by CTP and UTP. It is also much more thermolabile than E. coli ATCase. With respect to Pyrococcus abyssi and E. coli ATCases, Vibrio ATCase presents marked differences in composition which could be related to its psychrophilic character. The results of these structural and functional comparisons indicate that Vibrio 2693 ATCase is a suitable model for biochemical studies on structure-function relationships in a 'cold' allosteric enzyme. The operon is expressed from a promoter which is immediately followed by a pyrimidine-rich leader ORF terminating within a putative transcription attenuator. These genetic and enzymic data strengthen the evolutionary relationship already noted between Vibrionaceae and Enterobacteriaceae.
\end{abstract}

Keywords: aspartate carbamoyltransferase, psychrophiles, Vibrio

\section{INTRODUCTION}

The study of enzymic catalysis at low temperatures is gathering momentum (for reviews, see Russell, 1990, 1992; Feller et al., 1996; Gerday et al., 1997). One of the reasons for this increased interest in 'cold enzymes' is the large body of knowledge acquired during the last two decades on proteins from thermophilic organisms. Proteins functioning at high temperature are the result of a compromise between the intermolecular forces conferring enough rigidity to ensure stability and the

Abbreviations: ATCase, aspartate carbamoyltransferase; $C P$, carbamoylphosphate.

The EMBL accession number for the sequence reported in this paper is Y09786. need for functional flexibility (Jaenicke, 1995). On the other hand the architecture of a cold enzyme must ensure enough flexibility to make catalysis possible at a reduced energy cost (Feller et al., 1996). We would expect this need for high flexibility at low temperature to be paralleled by a decrease in stability. To a certain extent therefore, achievement of psychrophily could require molecular strategies converse to those adopted for thermophily. However, the latter appear multiple and are not yet clearly defined; there is thus a need to conduct research specifically focused on the molecular basis for psychrophily. At least two other reasons justify the study of enzymes adapted to cold: (1) the prospect of monitoring stability and catalysis independently (i.e. to produce stable enzymes active at low temperature) is of obvious biotechnological interest; and (2) several key metabolic enzymes are allosteric proteins and are 


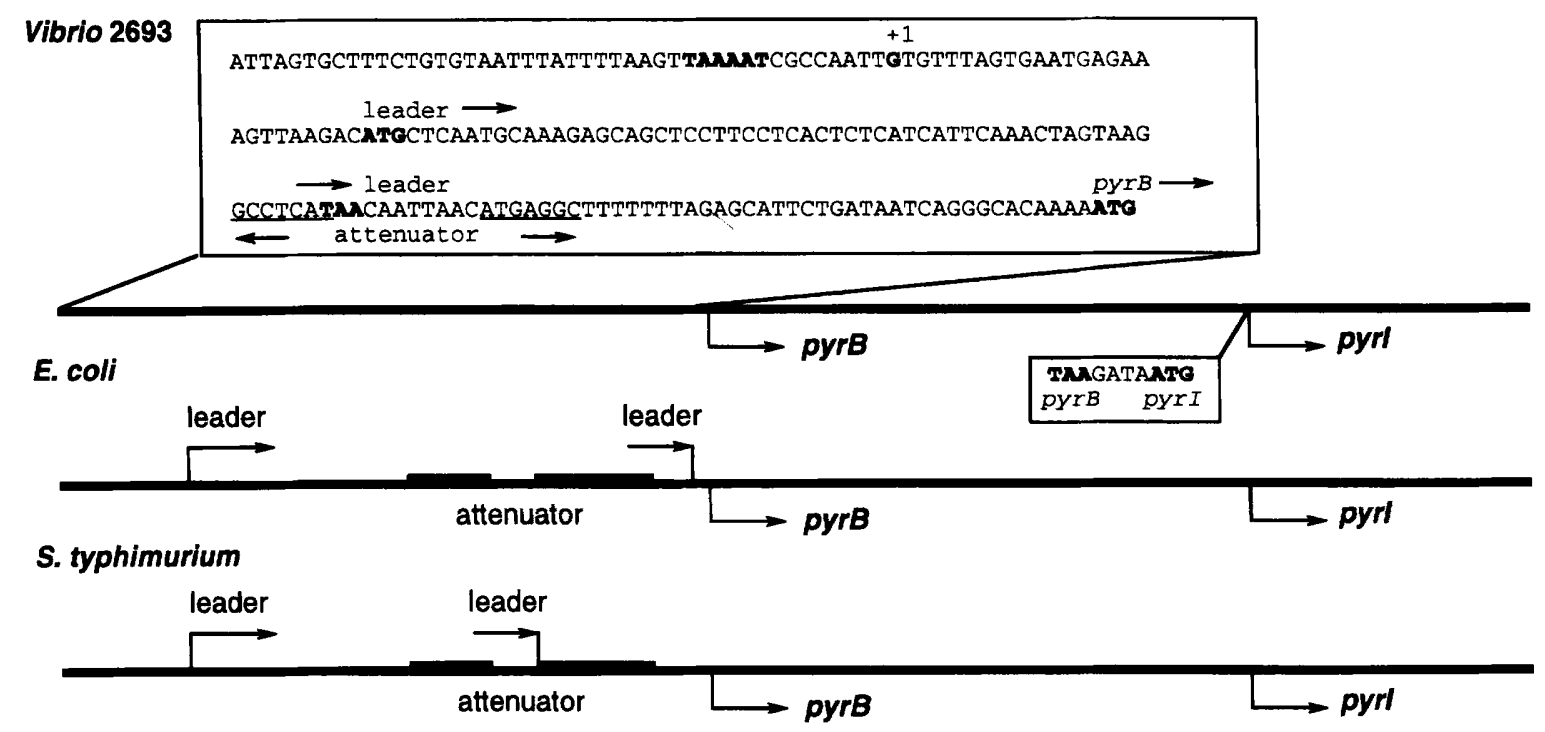

Fig. 1. Comparison of the promoter regions of the pyrBI operons in Vibrio 2693, E. coli and S. typhimurium. In the Vibrio sequence, bold characters indicate the -10 promoter element (TAAAAT), the experimentally determined transcription start point $(+1)$ and the start and stop codons of the leader ORFs. Inverted repeats are underlined.

therefore subject to the transmission of long-range intramolecular signals - this property emphasizes the need for structural flexibility.

Aspartate carbamoyltransferase (ATCase; EC 2.1.3.2), which catalyses the committed step of pyrimidine biosynthesis, is a particularly suitable enzyme to address the questions outlined above. The structure of Escherichia coli ATCase is known at high resolution (2.4 A; Lipscomb, 1994) and several other ATCases, including thermophilic ones, are currently being investigated (Van de Casteele et al., 1994, 1997a, b; Purcarea et al., 1997; Cunin, 1997). Enterobacterial ATCases belong to the so-called class B ATCases which are composed of two homotrimers of catalytic chains (c3) held together by their association with three homodimers of regulatory chains ( $\mathrm{r} 2$ ) harbouring the binding sites for the nucleotide effectors: CTP, an inhibitor, ATP, an activator and UTP which, in synergy with CTP, almost completely inhibits the enzyme (see Wild \& Wales, 1990). The structural genes for the $c$ and $r$ subunits have been designated $p y r B$ and $p y r l$, respectively; they constitute the pyrBI operon (reviewed by Neuhard $\&$ Kelln, 1996). Here we report on the properties of the first psychrophilic ATCase to be characterized at the enzymic and genetic level, a prerequisite to structural studies.

\section{METHODS}

Bacterial strains and plasmids. The host organism was psychrophilic Vibrio strain 2693 isolated by H. Rüger (Alfred-Wegener-Institut für Polar- und Meeresforchung, Bremerhaven, Germany) from the upper sediment layer of the deep Atlantic $(-2815 \mathrm{~m})$. The organism is unable to grow above $14{ }^{\circ} \mathrm{C}$ and has a maximal growth rate at $6^{\circ} \mathrm{C}$. E. coli

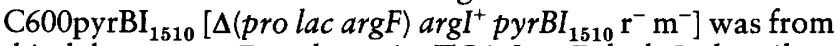
this laboratory. E. coli strain TG1 $[\operatorname{supE}$ hsd $\Delta 5$ thi $\Delta($ lac- pro $A B) \mathrm{F}^{\prime}$ (traD36 proAB $B^{+}$lacl $\mathrm{I}^{\mathrm{q}}$ lac $\left.\left.\mathrm{Z} \Delta \mathrm{M} 15\right)\right]$ was used as host for recombinant plasmids and for single-strand phagemidDNA rescue. The E. coli expression plasmid pTrc99A was from Pharmacia and pBluescript II KS + was from Stratagene.

Chemicals. Carbamoylphosphate (CP), L-aspartic acid, CTP, UTP, ATP, AMP, UMP, GMP and GTP were from Sigma and oligonucleotides from Gibco-BRL. Restriction enzymes and T4 DNA ligase were from Boehringer Mannheim.

Growth media. Marine Broth 2216 was from Difco. Arginineand uracil-free (AUF) rich synthetic medium was as described by Piérard \& Wiame (1964).

Culture conditions. E. coli was grown at $37^{\circ} \mathrm{C}$ in 853 broth (Glansdorff, 1965). Ampicillin was used at $50 \mu \mathrm{g} \mathrm{m}^{-1}$. Vibrio 2693 was grown aerobically at $6{ }^{\circ} \mathrm{C}$ in Marine Broth or AUF rich synthetic medium (with artificial sea water as minimal base; Rüger, 1988) to mid-exponential phase (about $5 \times 10^{8}$ cells $\mathrm{ml}^{-1}$ ).

DNA manipulations and transformation. Sau3A-digested DNA from Vibrio cells grown in Marine Broth was ligated with vector pTrc99A, pre-digested with BamHI, and dephosphorylated by incubating for $4 \mathrm{~h}$ at room temperature in the presence of ATP and ligase. Transformation conditions were as described by Dagert \& Ehrlich (1978). Small-scale plasmid preparations were obtained by the clear lysate procedure (Birnboim \& Doly, 1979). Large-scale preparations were recovered by Nucleobond AXPC100 (Macherey-Nagel).

Sequencing strategy. The SacI-PstI $2.4 \mathrm{~kb}$ fragment of plasmid pZYF70 was digested with Sau3A and subcloned into the BamHI site of pBluescript II $\mathrm{KS}+$ to generate a series of fragments. Single-strand phage template was isolated and purified according to Messing (1983). Nucleotide sequencing was performed by the dideoxy chain-termination method (Sanger et al., 1977), using the T7 sequencing kit from Pharmacia. Synthetic oligonucleotides were used as primers to sequence the templates prepared from pZYF70.

Southern hybridization. The blotting hybridization technique of Southern (1975) was applied at $68^{\circ} \mathrm{C}$ using random primed 
probe labelling and hybridization conditions as specified for the DIG labelling and detection system (Boehringer Mannheim).

Primer extension. The antisense oligonucleotide 5' GATGAGAGTGAGGAAGGAGC 3' (corresponding to positions +64 to +45 of the pyrBI operon) was used for extension by reverse transcriptase. The protocol was as described by Triezenberg (1995). Hybridization was performed at $42^{\circ} \mathrm{C}$.

Enzyme assays. Samples of cell-free extracts obtained by sonic disruption of mid-exponential phase cells were incubated at the required temperature for $10 \mathrm{~min}$ in the presence of $20 \mathrm{mM}$ L-aspartate, $5 \mathrm{mM} \mathrm{CP}$ and $50 \mathrm{mM}$ Tris $/ \mathrm{HCl}$ buffer, $\mathrm{pH} 9 \cdot 0$. The carbamoylaspartate formed was assayed colorimetrically as described by Foltermann et al. (1986). The influence of nucleotides on the rate of the reaction was determined as described by Xi et al. (1991). The specific ATCase activity was expressed as units (mg protein) ${ }^{-1}$, where a unit was the amount of enzyme which synthesized $1 \mu \mathrm{mol}$ carbamoylaspartate $h^{-1}$. Protein concentrations were determined by the Lowry method.

For measurements of ATCase thermostability, cell-free extracts (in $50 \mathrm{mM}$ Tris/ $\mathrm{HCl}$ buffer, $\mathrm{pH} 9 \cdot 0$ ) were incubated in the absence of substrates for $15 \mathrm{~min}$ at various temperatures and kept at $0{ }^{\circ} \mathrm{C}$ for at least $5 \mathrm{~min}$. Samples were taken and their activity was measured under standard assay conditions at $30^{\circ} \mathrm{C}$

\section{RESULTS AND DISCUSSION}

\section{ATCase activity in Vibrio 2693}

Vibrio 2693 is prototrophic and grows with a doubling time of $8.5 \mathrm{~h}$ at $6^{\circ} \mathrm{C}$ (optimal growth temperature) in AUF rich synthetic medium (Liang, 1997). In this medium the specific activity of ATCase was 8-9 units $(\mathrm{mg} \text { protein })^{-1}$. The presence of arginine and/or uracil in the medium did not influence this value.

\section{Cloning and sequencing Vibrio 2693 ATCase genes}

Vibrio 2693 DNA partially digested with enzyme Sau3A was used to construct a genomic DNA library in expression vector pTrc99A as described in Methods. A pyrBI deletion mutant of $E$. coli was transformed by library DNA and $\mathrm{Ura}^{+}$colonies were selected for on uracil-free rich synthetic medium at $30^{\circ} \mathrm{C}$. One such clone, found to contain an insert of about $12 \mathrm{~kb}$, was analysed further. After successive fragmentation with enzymes SacI and PstI, a $2.4 \mathrm{~kb}$ SacI-PstI insert was isolated that still complemented the E. coli pyrBI mutant in either orientation and in the same vector. Plasmid pZF70, harbouring this fragment in the orientation opposite to that of the pTrc promoter carried by the vector, was used for further studies.

Sequencing $1765 \mathrm{bp}$ from this fragment revealed a cluster of two ORFs homologous to the pyrB and pyrI genes, respectively, of $E$. coli and other organisms (see below and Fig. 3). Southern blotting experiments (data not shown) confirmed that the cloned fragment came from Vibrio 2693; under stringent conditions, the fragment did not hybridize with E. coli pyrBI DNA.

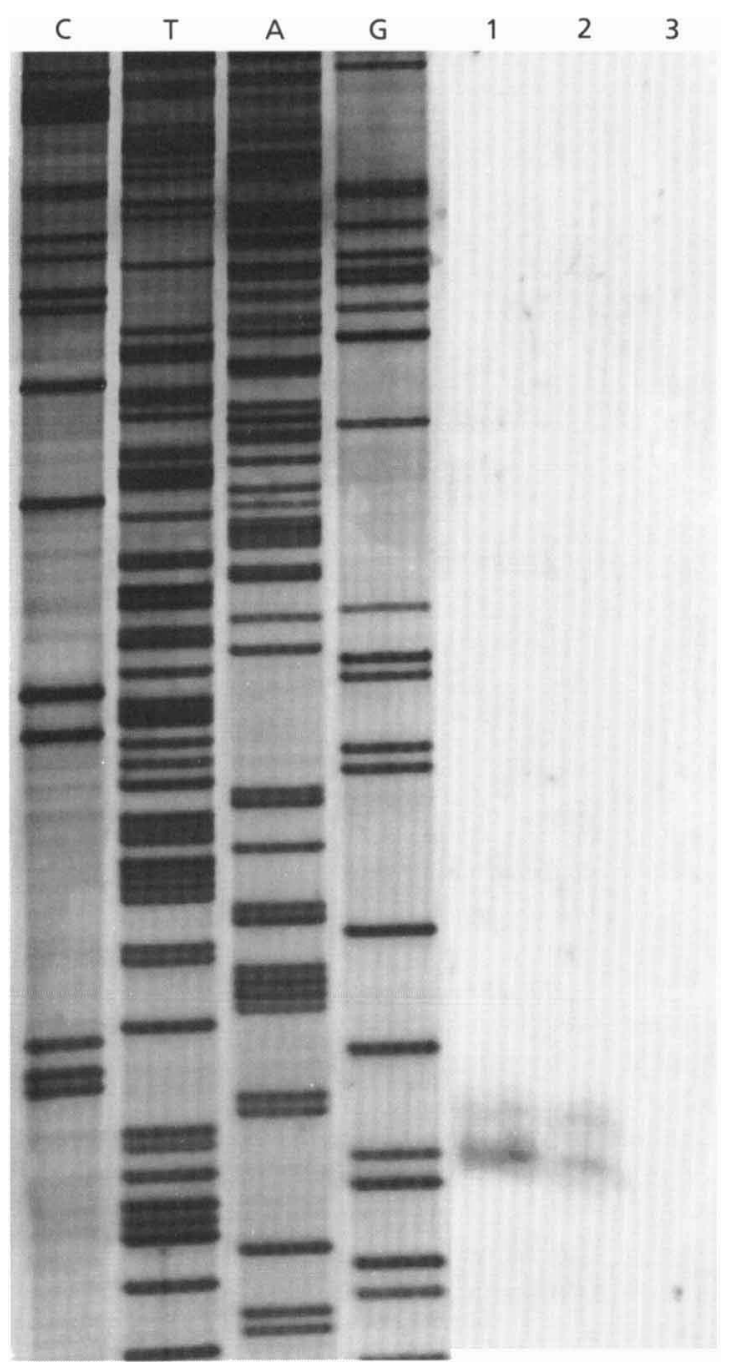

Fig. 2. Analysis of the transcription start sites at the pyrBI promoter in vivo by primer extension. Lanes: 1 and 2, different RNA preparations; 3, no RNA.

\section{Structure of the control region and start point of transcription}

The pyrB and pyrI homologues found in Vibrio are preceded by a control region which extends $141 \mathrm{nt}$ upstream from the putative $p y r B$ translation initiation codon (Fig. 1). Indeed, primer extension experiments located a predominant transcription start at a $G$ residue which is itself preceded by a putative -10 TAAAAT sequence element (Fig. 2). No corresponding -35 motif could be identified at a canonical distance, however. Since this is the first promoter to be characterized in this organism, it appears premature to comment on the possible significance of this observation. Between the experimentally determined transcription start point and the putative translation initiation codon, the sequence presents a 21 codon leader ORF preceded at $11 \mathrm{nt}$ by a possible ribosome-binding site (a GAG triplet) and terminated by a TAA codon located within a region presenting the features typical of a $\rho$-independent 
(a)

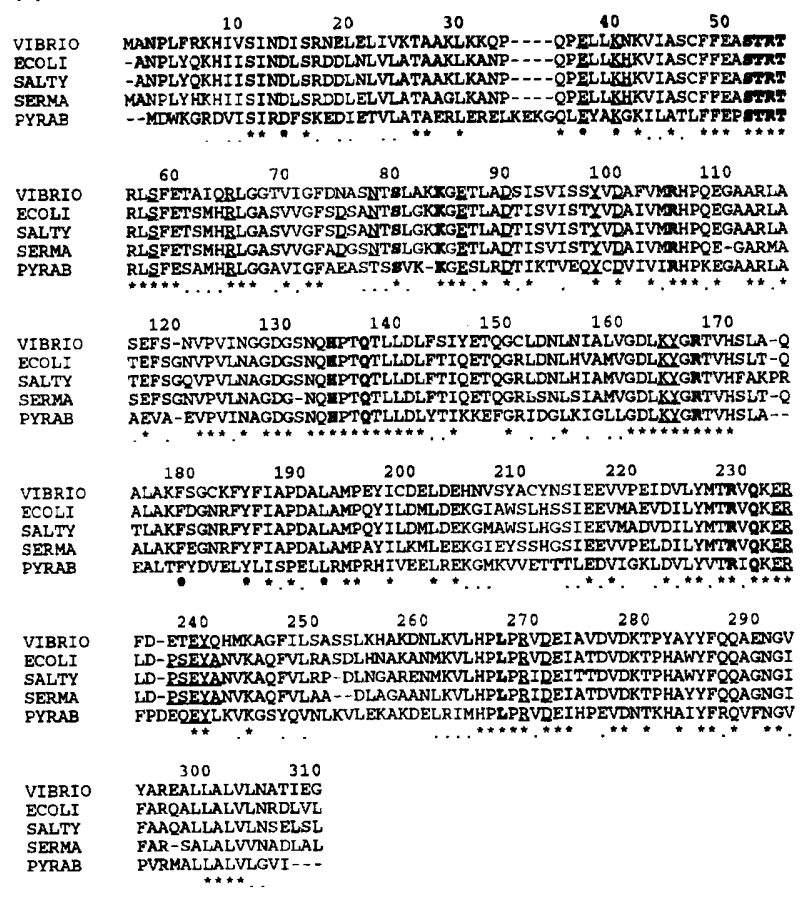

(b)

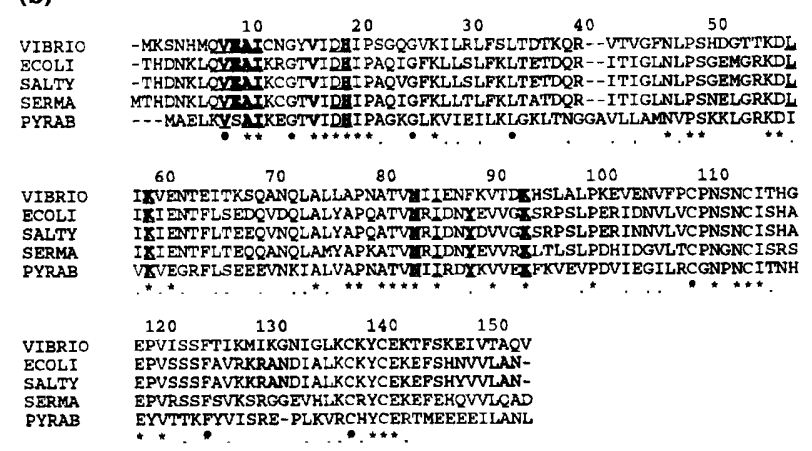

Fig. 3. Multiple alignment of the deduced amino acid sequences of Vibrio PyrB and Pyrl with sequences of ATCases from E. coli (ECOLI; accession nos P00479, P00478), S. typhimurium (SALTY; P08420, P08421), Serratia marcescens (SERMA; P19910, P19936) and Pyrococcus abyssi (PYRAB; P77918, PAU61765). (a) Catalytic chains. Residues which, in $E$. coli ATCase, form the catalytic site are indicated in bold, those implicated in the $c 1-c 4$ and $c 1-c 2$ interfaces are underlined. (b) Regulatory chains. Residues which, in E. coli ATCase, are involved in CTP binding are in bold, those involved in ATP binding are underlined. Asterisks indicate identical amino acids and dots indicate similar amino acids conserved in all protein sequences. attenuation site: two GC-rich sequences separated by 9 nt, capable of forming a stem-loop structure followed by 7 contiguous $T$ residues. Results obtained with a more distal primer showed that some of the reverse transcripts stop short of this putative stem-loop, suggesting that this structure may actually impede the progress of the transcriptase (not shown). The leader ORF contains a stretch composed almost exclusively of pyrimidines (from nt 48-63). A similar configuration of sequence elements was found in front of the $E$. coli and Salmonella typhimurium pyrBI operons (Roof et al., 1982; Michaels et al., 1987). It was originally suggested (Roof et al., 1982) and later established (Liu et al., 1989) that under conditions of pyrimidine starvation, RNA polymerase would pause at the pyrimidine-rich stretch; this would allow the ribosome translating the leader sequence to catch up with the polymerase and therefore prevent the formation of the attenuator structure when the tandem ribosome polymerase moves further downstream. Whether such regulation also operates in Vibrio is still unknown. However, it is worth emphasizing that, irrespective of possible regulation, the Vibrio control region is functional as far as gene expression is concerned since the primer extension data map the transcription start point at the onset of this region.

The Vibrio pyrB and pyrI genes are practically adjacent and appear to constitute an operon; only 4 bp separates the two coding regions. The $p y r B$ ORF has a coding potential of 310 aa with a predicted molecular mass of $34.4 \mathrm{kDa}$; pyrI would encode a 153 aa polypeptide of $16.8 \mathrm{kDa}$. The $\mathrm{G}+\mathrm{C}$ contents of $p y r B$ and $p y r l$ are 40 and $35 \mathrm{~mol} \%$ respectively, with a mean of $38 \%$ for the whole operon. These values are in agreement with the $G+C$ contents of five arginine genes from the same strain (Z. Liang \& Y. Xu, unpublished data).

\section{Analysis of the sequence}

The amino acid sequence of Vibrio and E. coli PyrB polypeptides are $74 \%$ identical. Given this high identity, the catalytic (c) chains of E. coli and Vibrio ATCases are likely to present closely comparable tertiary structures. The majority of the changes ( 52 of 81,53 of them being conservative) are localized in the so-called equatorial (or aspartate-binding) domain. In multiple amino acid sequence alignments, the active site residues that contact CP or aspartate in E. coli ATCase appear integrally conserved (Fig. 3; Lipscomb, 1994). Moreover, most of the residues which, in $E$. coli, are involved in interactions at the $c 1-c 2$ interface (i.e. between subunits of the same catalytic trimer) are conserved. The same is true for residues interacting at the $c 1-c 4$ interface (i.e. between subunits belonging to different catalytic trimers). In the pyrI subunit, which presents $56 \%$ similarity with the $E$. coli counterpart, the nucleotide effector binding site is almost completely conserved: of the 9 residues involved, tyrosine- 88 is replaced by phenylalanine and arginine- 95 by serine (Fig. 3; Lipscomb, 1994). The four cysteine residues involved in binding to the $\mathrm{Zn}^{2+}$ ion in $E$. coli ATCase are conserved.

\section{Properties of Vibrio ATCase}

The organization of the ATCase genes in Vibrio and their comparative sequence analysis strongly suggest that Vibrio and E. coli ATCase have the same quaternary structure. The molecular mass estimated by filtration through Superose P12 is in keeping with this inference: $320 \pm 20 \mathrm{kDa}$, thus compatible with a 2 (c3) 3 (r2) architecture since the sequence data would predict in that case a mass of $308 \mathrm{kDa}$. The approximate value of $300 \mathrm{kDa}$ reported for Vibrio natriegens (Kenny et al., 

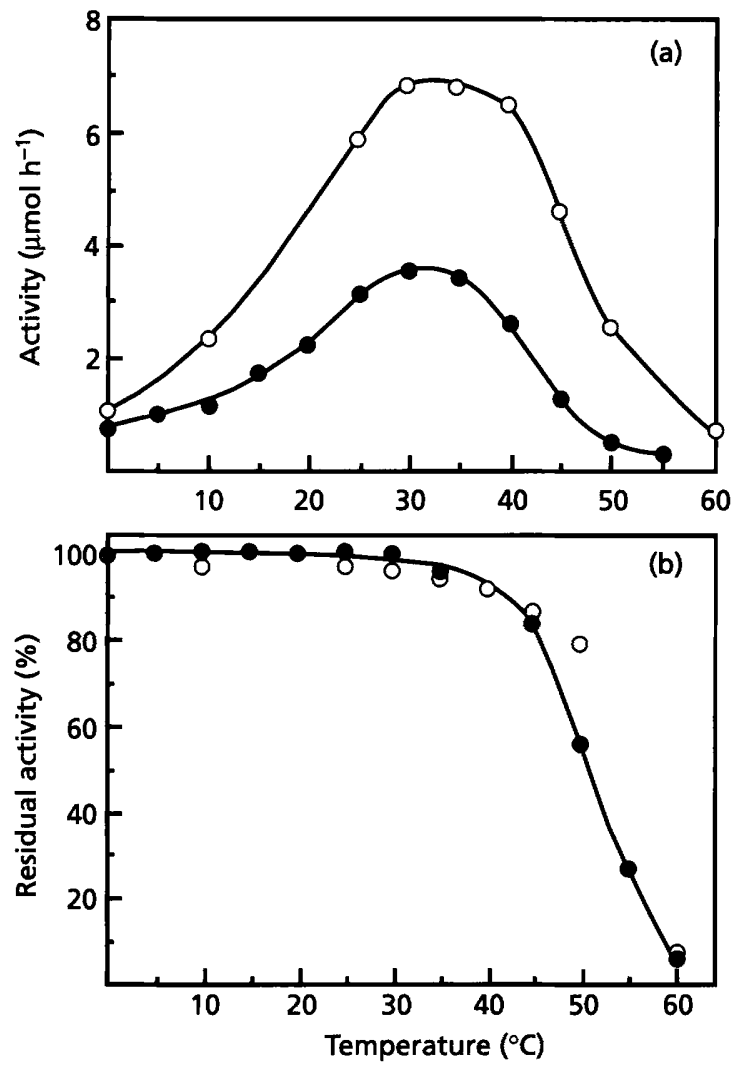

Fig. 4. Effect of temperature on activity (a) and stability (b) of Vibrio ATCase in a Vibrio extract $(O)$ and in a recombinant $E$. coli extract (O). (a) The temperature dependence of ATCase was determined with the standard assay (see Methods) performed at various temperatures. (b) The thermal stability was determined by measuring residual activity with the standard assay after a $15 \mathrm{~min}$ pre-incubation at various temperatures. Data presented are means of duplicate measurements; SEM is less than $10 \%$. In (b) $100 \%$ corresponds to $3.6 \mu \mathrm{mol} \mathrm{h}{ }^{-1}$ for the Vibrio extract (O) and $5.7 \mu \mathrm{mol} \mathrm{h}^{-1}$ for the recombinant $E$. coli extract (O).

1996) corroborates this estimation. The data thus reinforce the notion that in bacteria, class B ATCases are characteristic of the species clustered in the $\gamma-3$ group of Gram-negative Proteobacteria (Kenny et al., 1996). It is therefore striking that class B ATCases also appear to be characteristic of Archaea (Bult et al., 1996; Purcarea et al., 1997; Durbecq et al., 1997). A thorough discussion of evolutionary relationships between carbamoyltransferases is presented in Labédan et al. (1998).

The study of the $\mathrm{pH}$ response suggests that Vibrio ATCase activity reaches a maximum at $\mathrm{pH}$ 9-10.

The temperature dependence profile of Vibrio ATCase (either native or recombinant) indicates an apparent optimum between 30 and $35^{\circ} \mathrm{C}$ (Fig. 4a). Psychrophilic enzymes quite commonly display activity at temperatures much higher than the growth optimum of their host (see examples in Morita, 1975, 1992; Russell, 1990, 1992; Davail et al., 1994; Feller et al., 1996). From the physiological point of view, however, it seems relevant that Vibrio ATCase is still considerably active
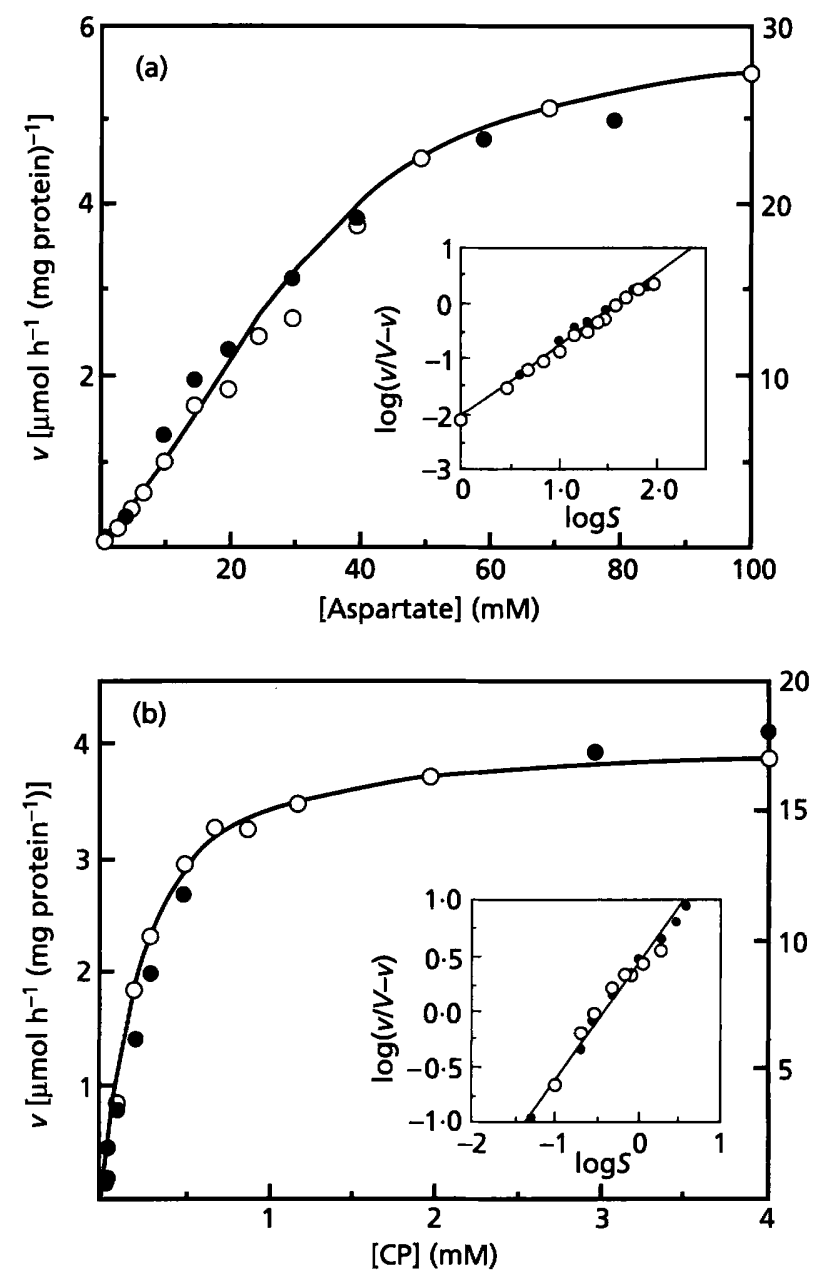

Fig. 5. Saturation curves of Vibrio ATCase by aspartate (a) and CP (b). ATCase activity was measured as described in Methods in the presence of increasing concentrations of aspartate or CP. Fixed CP and aspartate concentrations were $5 \mathrm{mM}$ and $20 \mathrm{mM}$, respectively. Left $y$-axis, activity in a Vibrio extract (O); right $y$ axis, activity in a recombinant $E$. coli extract $(O)$. The inserts show the corresponding Hill plots. Data presented are means of duplicate measurements; SEM is less than $5 \%$.

in the actual temperature range (up to $14^{\circ} \mathrm{C}$ ) of its host: at $2{ }^{\circ} \mathrm{C}$, activity approaches $20 \%$ of the optimum and $30 \%$ at $6{ }^{\circ} \mathrm{C}$. An Arrhenius plot of the data gave an activation energy $\left(E_{\mathrm{a}}\right)$ of $41.6 \mathrm{~kJ} \mathrm{~mol}^{-1}$. By comparison, ATCase from Pyrococcus abyssi, a hyperthermophilic archaeobacterium, has an $E_{\mathrm{a}}$ of $65.6 \mathrm{~kJ} \mathrm{~mol}^{-1}$ in the $20-50{ }^{\circ} \mathrm{C}$ range but this shifts to $40.9 \mathrm{~kJ} \mathrm{~mol}^{-1}$ in the $50-70{ }^{\circ} \mathrm{C}$ range (Purcarea et al., 1994).

Thermostability profiles also proved indistinguishable for native and recombinant ATCase (Fig. 4b); $15 \mathrm{~min}$ incubation at $60^{\circ} \mathrm{C}$ inactivated the enzyme more than $90 \%$. Half-lives were about $4 \mathrm{~min}$ at this temperature and $8 \mathrm{~min}$ at $50^{\circ} \mathrm{C}$ (data not shown). Vibrio ATCase is thus considerably more labile than E. coli ATCase which loses only $25 \%$ of its activity after $6 \mathrm{~h}$ incubation at $60^{\circ} \mathrm{C}$ (Kerbiriou \& Hervé, 1972). It is therefore interesting to examine whether the differences in amino 


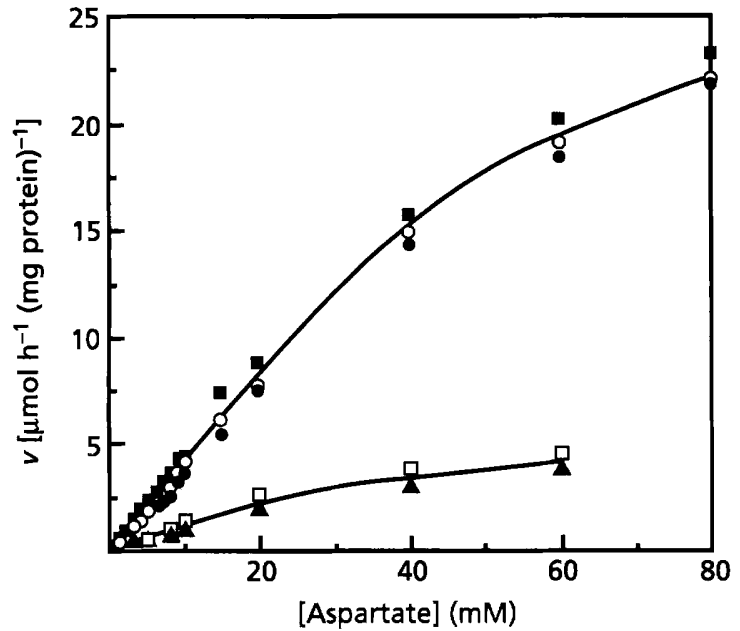

Fig. 6. Influence of NTPs on the aspartate saturation curve of Vibrio ATCase produced in E. coli. ATCase activity was measured as described in Methods in the presence of increasing concentrations of aspartate without effector (O) or with $2 \mathrm{mM}$ UTP (O), $5 \mathrm{mM}$ ATP ( $\square), 2 \mathrm{mM}$ CTP ( $\square$ ) or $2 \mathrm{mM} \mathrm{CTP}+2 \mathrm{mM}$ UTP ( $\boldsymbol{\Delta})$. Data presented are means of at least two separate experiments; SEM is less than $5 \%$.

acid composition already noted between $E$. coli ATCase and its hyperthermophilic homologue from $P$. abyssi also exist in Vibrio ATCase and whether they are not accentuated in this enzyme. The most notable features of the mesophilic ATCase with respect to the thermophilic one were a lower number of charged residues likely to participate in stabilizing interactions (arginine, glutamate and lysine), a higher number of the thermolabile residues asparagine and glutamine and a higher number of serine residues (Purcarea et al., 1997). The same trend is observed in Vibrio ATCase but, with respect to $E$. coli, the arginine content (and also the $\mathrm{R} / \mathrm{R}+\mathrm{K}$ ratio) undergoes a further and remarkable decrease (14 residues instead of 23), whereas the number of cysteine residues, susceptible to enhanced oxidation at high temperature, rises from 5 to 10 . This is a striking increase indeed, considering that four of these cysteines are already involved in the binding of one atom of $\mathrm{Zn}$ in the $r$ chain and are expected to be conserved in all class B ATCases. On the whole, therefore, Vibrio ATCase presents characteristics which are in keeping with its psychrophilic character.

The response to substrates and effectors was investigated at $30^{\circ} \mathrm{C}$. The aspartate saturation curves suggest homotropic interactions with respect to this substrate $\left(n_{\mathrm{H}}=\right.$ $1.3 \pm 0.05$ ), with a $S_{0.5}$ of $40 \pm 4 \mathrm{mM}$ (Fig. 5a). The curves obtained for CP were hyperbolic, with an apparent $K_{\mathrm{m}}$ of $0.3 \pm 0.02 \mathrm{mM}$ (Fig. $5 \mathrm{~b}$ ).

The analysis of the effect of nucleotides (see Fig. 6 for data on the recombinant enzyme) showed inhibition by CTP, while ATP and UTP had no effect and no CTP/UTP synergy was observed; the response of the native enzyme was not significantly different (data not shown). The response of the native enzyme to ATP and
CTP was also investigated at $15^{\circ} \mathrm{C}$ and again no significant differences were noted; moreover AMP, GMP, UMP and GTP were without significant effect at the concentration tested $(5 \mathrm{mM})$, whereas succinate (an analogue of aspartate) and phenylglyoxal were inhibitory (data not shown). The response of Vibrio ATCase to various ligands thus resembles that of $E$. coli ATCase except for the lack of activation by ATP and the absence of CTP/UTP synergy. Since the nucleotide binding site of the enzyme is highly conserved (including residues aspartate-19 and leucine-58, both specific for ATP binding in E. coli ATCase), it is likely that the insensitivity to ATP is due to substitutions in residues playing a role in the transmission of the regulatory signal.

\section{Conclusions}

The temperature response of Vibrio ATCase, the marked differences observed between its amino acid composition and that of mesophilic and thermophilic homologues and its close structural relationship to the $E$. coli paradigm indicate that it is a suitable model for biochemical studies on structure-function relationships in a 'cold' allosteric enzyme.

\section{ACKNOWLEDGEMENTS}

This work was supported by the Belgian Foundation for Joint and Fundamental Research (FKFO), by the Flanders Action Programme Biotechnology, by the EEC programmes Coldzymes and Eurocold, and by a Concerted Action between the Belgian State and the Free University of Brussels (VUB).

\section{REFERENCES}

Birnboim, H. C. \& Doly, J. (1979). A rapid alkaline extraction procedure for screening recombinant plasmid DNA. Nucleic Acids Res 7, 1513-1523.

Bult, C. J., White, O., Olsen, G. J. \& 37 other authors (1996). Complete genome sequence of the methanogenic archaeon, Methanococcus jannaschii. Science 273, 1058-1073.

Cunin, R. (1997). Carbamoylphosphate metabolism in thermophiles and hyperthermophiles - a perspective. Paths Pyrimidine Int Newsl 5, 37-49.

Dagert, M. \& Ehrlich, S. D. (1978). Prolonged incubation in calcium chloride improves the competence of Escherichia coli cells. Gene 6, 23-28.

Davail, S., Feller, G., Narinx, E. \& Gerday, C. (1994). Cold adaptation of proteins. Purification, characterisation and sequence of the heat-labile subtilisin from the antarctic psychrophile Bacillus TA41. J Biol Chem 269, 17448-17453.

Durbecq, V., Thia-Toong, T. L., Charlier, D., Roovers, M., Legrain, C. \& Glansdorff, N. (1997). Aspartate carbamoyltransferase from the extremely thermophilic archaeon Sulfolobus solfataricus: gene cloning, sequence analysis and enzyme characterisation. Arch Physiol Biochem 106, B6.

Feller, G., Narinx, E., Arpigny, J. L., Aittaleb, M., Baise, E., Genicot, S. \& Gerday, C. (1996). Enzymes from psychrophilic organisms. FEMS Microbiol Rev 18, 189-202.

Foltermann, K. F., Beck, D. A. \& Wild, J. R. (1986). In vivo formation of hybrid aspartate transcarbamoylases from native 
subunits of divergent members of the family Enterobacteriaceae. J Bacteriol 167, 285-290.

Gerday, C., Aittaleb, M., Arpigny, J. L., Baise, E., Chessa, J. P., Garsoux, G., Petrescu, I. \& Feller, G. (1997). Psychrophilic enzymes: a thermodynamic challenge. Biochim Biophys Acta 1342, 119-131.

Glansdorff, N. (1965). Topography of cotransductible arginine mutations in Escherichia coli K12. Genetics 51, 167-179.

Jaenicke, R. (1995). Protein folding and association: significance of in vitro studies for self-organization and targeting in the cell. Curr Top Cell Regul 34, 209-314.

Kenny, M. J., McPhail, D. \& Shepherdson, M. (1996). A reappraisal of the diversity and class distribution of aspartate transcarbamoylases in Gram-negative bacteria. Microbiology 142, 1873-1879.

Kerbiriou, D. C. \& Hervé, G. (1972). An aspartate transcarbamylase lacking catalytic subunit interactions. I. Disconnection of homotropic and heterotropic interactions under the influence of 2thiouracil. J Mol Biol 64, 379-382.

Labédan, B., Boyen, A., Baetens, M. \& 16 other authors (1998). The evolutionary history of carbamoyltransferases: a complex set of paralogous genes was already present in the last universal common ancestor. J Mol Evol (in press).

Liang, 2. (1997). Physiology and molecular biology of enzymatic carbamoylation in marine psychrophilic bacteria. $\mathrm{PhD}$ thesis, Free University of Brussels.

Lipscomb, W. N. (1994). Aspartate transcarbamylase from Escherichia coli: activity and regulation. Adv Enzymol 68, 67-152.

Liu, C. \& Turnbough, C. L., Jr (1989). Multiple control mechanisms for pyrimidine-mediated regulation of $\mathrm{pyr} B I$ operon expression in Escherichia coli K12. J Bacteriol 171, 3337-3342.

Messing, J. (1983). New M13 vectors for cloning. Methods Enzymol 101, 20-78.

Michaels, G., Kelln, R. A. \& Nargang, F. E. (1987). Cloning, nucleotide sequence and expression of the pyrBI operon in Salmonella typhimurium LT2. Eur J Biochem 166, 55-61.

Morita, R. Y. (1975). Psychrophilic bacteria. Bacteriol Rev 39, 144-167.

Morita, R. Y. (1992). Low-temperature environments. In Encyclopedia of Microbiology, vol. 2, pp. 625-637. Edited by J. Lederberg. New York: Academic Press.

Neuhard, J. \& Kelln, R. A. (1996). Biosynthesis and conversions of pyrimidines. In Escherichia coli and Salmonella typhimurium: Cellular and Molecular Biology, pp. 580-599. Edited by F. C. Neidhardt. Washington, DC: American Society for Microbiology.

Piérard, A. \& Wiame, J. M. (1964). Regulation and mutation affecting a glutamine dependent formation of carbamoylphosphate in Escherichia coli. Biochem Biophys Res Commun 15, 76-81.

Purcarea, C., Erauso, G., Prieur, D. \& Hervé, G. (1994). The catalytic and regulatory properties of aspartate transcarbamylase from Pyrococcus abyssi, a new deep-sea hyperthermophilic archaeobacterium. Microbiology 140, 1967-1975.

Purcarea, C., Hervé, G., Ladjimi, M. M. \& Cunin, R. (1997). Aspartate transcarbamylase from the deep-sea hyperthermophilic archaeon Pyrococcus abyssi: genetic organization, structure and expression in Escherichia coli. J Bacteriol 179, 4143-4157.

Roof, W. D., Foltermann, K. F. \& Wild, J.R. (1982). The organization and regulation of the pyrBI operon in E. coli includes a rho-independent attenuator sequence. Mol Gen Genet 187, 391-400.

Rüger, H. J. (1988). Substrate-dependent cold adaptations in some deep-sea sediment bacteria. Syst Appl Microbiol 11, 90-93.

Russell, N. J. (1990). Cold adaptation in microorganisms. Philos Trans $R$ Soc Lond B326, 535-553.

Russell, N. J. (1992). Physiology and molecular biology of psychrophilic microorganisms. In Molecular Biology and Biotechnology of Extremophiles, pp. 203-224. Edited by R. A. Herbert \& R. J. Sharp. New York: Chapman and Hall.

Sanger, F., Nicklen, S. \& Coulson, A. R. (1977). DNA sequencing with chain-terminating inhibitors. Proc Natl Acad Sci USA 74, 5463-5467.

Southern, E. M. (1975). Detection of specific sequences among DNA fragments separated by gel electrophoresis. $J \mathrm{Mol}$ Biol 98, 503-517.

Triezenberg, S. J. (1995). Primer extension. In Current Protocols in Molecular Biology, vol. 1, unit 4.8. Edited by F. M. Ausubel, R. Brent, R. E. Kingston, D. D. Moore, J. D. Seidman, J. A. Smith \& K. Struhl. Chichester: Wiley.

Van de Casteele, M., Demarez, L., Legrain, C., Chen, P. G., Van Lierde, K., Piérard, A. \& Glansdorff, N. (1994). Genes encoding aspartate carbamoyltransferases of Thermus aquaticus ZO5 and Thermotoga maritima MSB8: modes of expression in E. coli and properties of their products. Biocatalysis 11, 165-179.

Van de Casteele, M., Chen, P., Roovers, M., Legrain, C. \& Glansdorff, N. (1997a). Structure and expression of a pyrimidine gene cluster from the extreme thermophile Thermus strain ZO5. J Bacteriol 179, 3470-3481.

Van de Casteele, M., Legrain, C., Demarez, L., Chen, P., Piérard, A. \& Glansdorff, N. (1997b). Molecular physiology of carbamoylation under extreme conditions: what can we learn from extreme thermophilic microorganisms? Comp Biochem Physiol 118A, $463-473$.

Wild, J. R. \& Wales, M. E. (1990). Molecular evolution and genetic engineering of proteins domains involving aspartate transcarbamylase. Annu Rev Microbiol 44, 193-218.

Xi, X. G., Van Vliet, F., Ladjimi, M. M., De Wannemaeker, B., De Staercke, C., Glansdorff, N., Piérard, A., Cunin, R. \& Hervé, G. (1991). Heterotropic interactions in Escherichia coli aspartate transcarbamylase. Subunit interfaces involved in CTP inhibition and ATP activation. J Mol Biol 220, 789-799.

Received 17 November 1997; revised 19 January 1998; accepted 11 February 1998. 